\title{
China: Economic magnet or rival? Framing of China in the Dutch- and French-language elite press in Belgium and the Netherlands
}

\section{Lutgard Lams}

KU Leuven Campus Brussels, Department of Languages and Literature, Brussel, Belgium

\begin{abstract}
Given the increasing attention China has attracted on a global scale over the last few decades, ample academic research has been conducted into the types of China discourses, spread through the media. Studies have pointed at a mounting Sino-phobic discourse in some US media, which prompts the question whether similar attitudes and frames emerge in non-English media narratives. Hence, this study examines how the Belgian as well as the Dutch elite press engage with the new world player. It combines a content analysis, looking into thematic hierarchies and tone/perspective with a critical discourse analysis, retrieving discursive practices, such as evaluative positioning and framing of the country and its main actors. In addition, the article integrates framing research with a Gramscian notion of media hegemony to investigate whether the particular source selection leaves room for a heteroglossic environment.
\end{abstract}

\section{Keywords}

Belgian and Dutch press narratives, discourse analysis, framing analysis, ideology, language pragmatics, media coverage, representation of China

\section{Introduction}

Given the increasing media attention China has attracted on a global scale over the last few decades because of its newly gained position as a world player in the

\section{Corresponding author:}

Lutgard Lams, KU Leuven Campus Brussels, Department of Languages and Literature, Warmoesberg 26, 1000 Brussel, Belgium.

Email: lut.lams@kuleuven.be 
geopolitical and economic arenas, it is natural for China to show an interest in how these achievements have been perceived by the stakeholders, co-players or onlookers to the global chess game. According to a recent survey of attitudes toward China, conducted by The Global Poll Center of the Chinese newspaper the Global Times, China is viewed by respondents in 14 countries as confident, belligerent and arrogant and only a tiny minority describes China as 'peaceful.' This poll confirms earlier studies pointing at mounting Sino-phobic discourse in some US media and prompts the question whether this sentiment is echoed in other Western countries. One may wonder whether similar attitudes and frames emerge in media narratives (re)produced for a non-English speaking audience.

This study, therefore, examines how the Belgian and Dutch elite press engage with China and explores whether there is any differential treatment of the main Chinese actors, groups, structures, relations or events. ${ }^{1}$ The corpus consists of all news and op-ed articles published over 1 year (November 2012 - October 2013) in the mainstream elite press of both French and Dutch-language communities in Belgium (De Morgen, De Standaard, De Tijd, le Soir and La Libre Belgique) and two widely spread Dutch dailies, de Volkskrant and NRC Handelsblad. More generally, the article sets out to uncover whether and how the news media construct ideological meanings and will do so by investigating systematic topic selection and patterns in linguistic choice-making. It also probes into source selection to assess diversity and balance of voices to answer the question whether there is room for a heteroglossic environment.

\section{Literature on China news coverage}

The very reason for starting this research was the criticism leveled at Western media institutions by Chinese policymakers and researchers during the run-up to the Beijing Olympics in 2008. Government officials often accuse Western media of disparaging China's international image. This explains the reason why the Chinese newspaper, the government-run Global Times, conducted a survey of attitudes toward China, the result of which only confirmed the perception that China is not usually depicted in peaceful terms. Chinese civil society has also joined the criticism in posting messages on internet fora about the perceived negative Western media bias against China. This criticism inscribes itself in the broader post-colonial critique on Western ethnocentric depiction of the Orient, going back to the seminal work Orientalism by Edward Said (1978, 2003). According to Said, Orientalism depends for its strategy on a flexible positional superiority, which puts the Westerner in a whole series of possible relationships with the Orient without ever losing him the relative upper hand (Said, 2003: 7). Western media have been criticized since the 1960s in diverse disciplines such as cultural studies and communication studies for a biased, negative representation of the developing world. In this critique, the model of 'Representation of the Other' is believed to induce social exclusion and oppression. The 'rhetoric of Othering' (Riggins, 1997) frames a contrasting image of the Other, often those people who are not my people or one of us. 
According to a study by Ono and Jiao (2008) a 'yellow peril' motif and rising Sino-phobic discourse appeared to figure centrally in the US media. Blog messages by the expat Chinese author Lulu Wang, calling for a more balanced approach to China, ${ }^{2}$ were echoed by Decoster (2008) and Jonckheere (2008) publishing op-ed articles in Belgian newspapers with complaints of the narrow lenses, lack of self-reflection, and disinformation of the Western media coverage. However, no information is provided as to which Western media are analyzed. Neither is the methodology of the analysis clarified. The Western voice, therefore, tends to be essentialized and frozen into one monolithic bloc.

Another question is whether the type of negative framing of China only happens in Western media? In this respect, it may be interesting to also analyze Japanese, Indian, Hong Kong, Taiwanese media accounts, to name just a few, and see whether the Chinese framing packages in these regions are similar to the ones in some Western media products.

Yet, the question raised by Lulu Wang is worth our attention, especially in view of other studies corroborating the gist of Wang's message. The analysis by Richter and Gebauer (2011) of the 2008 China narratives in the German print media demonstrated that half of the corpus referred to China in (positive as well as negative) stereotype-reinforcing ways without further reflection. Beyond that, the authors noted a surprisingly broad range of topics in comparison to reporting from other regions (2011: 3). Cultural aspects reportedly lent 'unusual' weight with a $9.2 \%$ share of total reporting (Richter and Gebauer, 2011). Other areas of central importance to social transformation, such as social issues, education, science and technology were, however, completely disregarded. Reporting was found to be dominated by the media logic with a core agenda focusing on negative news values, such as conflict and violence. In addition, the conflict-laden core agenda was considered to be shaped by Germany's self-positioning in relation to China in terms of competition of ideological world order strategies. Ideology thus was seen to underlie the rationale of topic choice, tilting toward themes of relevance to Western societies, such as democracy, liberalism and freedom in relation to conditions in China (Richter and Gebauer, 2011).

Along the same lines, a study about US news coverage of student demonstrations in South Korea in 1980 and China in 1989 (Kobland et al., 1992) identified an overall anti-communist framing process beyond the theme selection. Instead of a merely anti-communist frame, Lee (2002) derived three ideological packages characterizing US press coverage of China in his framing analysis of the news discourse about the American China policy in the New York Times between 1990 and 2000, namely containment (by using trade as a weapon to punish China for its poor human rights record), engagement (by linking achievable human rights conditions to trade), and globalization (by bringing China into international organizations to enhance US trade and China's handling of human rights issues) (Lee, 2002; Willnat and Luo, 2011: 258).

The study by Richter and Gebauer (2011) of the German corpus, however, found that, despite the specific news agenda and self-centeredness in the topic selection 
process, the topics were discussed in-depth, taking internal Chinese dynamics in all their complexity into consideration and providing different perspectives of the issues involved. Yet, the authors found that, 'due to the media's focus on dissidents and minority issues, the tension encompassing domestic policy and social transformation, which is of key importance for civil protests in China, did not receive the attention needed for a broader understanding of Chinese realities' (Richter and Gebauer, 2011: 6). Similarly, Zhao (2013) argues for a more comprehensive approach in communication studies, comprising the intersection of class and nation and a reorientation toward how the local culture engages with modernity. In a more longitudinal study about the framing of China in the German press from 1986 to 2006, Wilke and Achatzi's (2011) indicate that the assessment of China does not appear to take a linear development, as positive and negative frames alternate depending on emerging events or crises. Although assessment of China has improved in recent years in German newspapers (especially the Frankfurter Allgemeine Zeitung), the authors conclude that the assessment was disturbed again and again by single events and occasions that provoked criticism of China and the Chinese government's conduct (Wilke and Achatzi, 2011: 362).

Yet, other diachronic studies, such as Peng's (2004) comparison of the China news stories in the New York Times and Los Angeles Times between 1992 and 2001 and Stone and Xiao's (2007) content analysis of the US news magazines Newsweek, Time, US News and World Report between 1984 and 1999, found that the overall tone of news became more negative over time, despite the growing emphasis on economic rather than political news frames. The negative image of China was also noted in a study of the representation of the three T's (Tibet, Taiwan, Turkestan) in the Belgian press, adopting a villain/victim framework with China, most often depicted in an active, negative semantic role (Lams, 2013). While all contending voices were given a platform, negative messages about China tended to prevail. Ideological positions were found to underlie a number of narratives in 'attributing positive properties to the Tibetan protagonists and casting China in the negative light of the human rights abuser' (2013: 61).

Media realities, emerging from these ideological constructions, also appear to be different depending on the national interests of the particular country in which media organizations operate. For example, Wu (2006) found a differential treatment by the Chinese Xinhua News Agency and Associated Press in their coverage of HIV/AIDS in China. While China came out as a 'dishonest' and 'oppressive' government in the AP framing, Xinhua stories reportedly praised the Chinese government for its 'open attitude' in dealing with the problem. Similar divergences were found in the comparative analysis by Lams (2010) of US and Chinese press coverage of the 2001 Hainan diplomatic standoff between China and the United States after the spy plane collision. The US and Chinese narratives were found to follow the national foreign policy agendas. That project investigated how language of empowerment and alienation discursively shapes social reality and contributes to disseminating ideological assertions, building and sustaining myths, and portraying the 'Self' and the 'Other' in antagonistic ways (2010: 315). Lams thus complements 
the postcolonial literature focusing on Western media misrepresentation of the Oriental Other by critically assessing the Chinese media performance in representing the Western Other. The study's findings support Huang and Leung's (2005) argument that 'scholars of communications and journalists might need to adopt new perspectives and professional routines to defuse the complex dilemma of representing others instead of taking the mainstream critical assumptions of the concept [of Othering] at face value' (Huang and Leung, 2005: 303-304). While acknowledging the merit of the concept 'Othering,' Lams supports Huang and Leung's argument that 'there are internal contradictions and factors with compelling forces working jointly towards the textual outcome, which commands the analyst's attention' (2005: 305). As Clifford states, one cannot 'ultimately escape procedures of dichotomizing, restructuring and textualizing in the making of interpretive statements about foreign cultures' (1988: 261). Rather than the deliberate agenda-setting or bias of foreign journalists, Huang and Leung found the negative coverage of China in the Western press to result from China's own policies and actions, given the differential treatment in the Western press between the Vietnamese and Chinese official handling of the SARS crisis, while both nations are traditionally described in anti-Communist media frames.

Yet, some Chinese officials have approached this perceived negative China framing as a 'conspiracy between the media and the West (especially the US government) to contain China' (Huang and Leung, 2005: 303). This is not unlike Iranian official comment in the 2009 post-electoral demonstrations about Western conspiracy and Egyptian official accusation of Western incitement of demonstrators at the Tahrir Square in Cairo in 2011 and 2014.

The divergence in academic analyses of China framing in Western media demonstrates the importance of analytical differentiation between the various media outlets under investigation. This can also be derived from the results of a study by Sparks (2010) about three British newspapers' China coverage in 2008. Sparks concluded that the social composition of the papers' readerships dictated the framing process. Elite papers in Britain, catering to a relatively wealthy and welleducated readership, brought a more diverse and less negatively framed coverage of China than their more populist rivals. ${ }^{3}$

When it comes to China coverage on TV news, Willnat and Luo (2011), who participated in an international project analyzing presentation of foreign news on TV, argue that foreign TV news does not only offer insufficient coverage of China, but it should also pay more attention to China's cultural and social issues (Cohen, 2011: 252; Willnat and Luo, 2011: 270). The lack of coverage of social issues was also reported by Richter and Gebauer (2011) and the present article will likewise conclude that coverage in the Belgian and Dutch press of social issues in contemporary China is very limited. However, there has been a substantial growth in overall media attention to China, especially in the printed press, as was demonstrated in the diachronic study by Zhang (2010) of the China coverage in the European magazine The Economist and the newspaper The International Herald Tribune between 1989 and 2005. 
While most of the above studies primarily conducted classical quantitative content analyses, the present analysis adopts a more qualitative approach, looking into the genesis of the particular frames. Yet, besides the mainly discursive focus of the article, general information about deemed newsworthiness in terms of number of articles and general tone of the articles will be presented, although this is not the typical content analysis with statistical tests of coder reliability and statistical significance of differences between the newspapers.

\section{Research theories and methodological considerations}

The current analysis is based on the theoretical perspective that cultural and political identities are partly produced by individual experience, partly by mediated collective experiences offered by the media, which promote and negotiate particular versions of reality through the combined tools of graphic and textual language. Indeed, construction or representation of reality passes through the mediation of these languages, which have immense power to construct/change existing perceptions and interpretations of realities. The implications of linguistic choice making for meaning generation and interpretation will be examined drawing on theoretical and methodological insights from the fields of media discourse analysis, language pragmatics, framing theory and social representation theory.

Further to the theoretical points on Orientalist depictions in Western media representation and the questioning of the mainstream critical approach to Western media representation of the Other by Huang and Leung (2005), this study also finds the social representations theory illuminating for media research. As Höijer (2011) puts it, 'social representations are about processes of collective meaning-making resulting in common cognitions which produce social bonds uniting societies, organizations and groups' (2011: 3). Drawing on insights from Moscovici (2000), Höijer specifies two communicative mechanisms explaining the transformation of ideas into what is perceived of as common sense.

Of particular relevance to our study is one of these two communicative mechanisms, namely anchoring via antinomies, for example, oppositional distinction between various groups and identities. Olausson discusses how a European identity is constructed in the Swedish media, by depicting a conflictual relationship between 'Us,' the EU, who acknowledge climate change as a serious threat and want to take action against it, and 'Them,' the United States, who refuse to even discuss regulations (Olausson, 2010). This article combines social representations theory and critical discourse theory, the applications of which can be most readily found in critical discourse analysis (CDA), which looks for unequal power relations instantiated in discourse, seen as a social practice.

The import of language pragmatics in such a critical discourse analysis can be seen in our study's focus on discursive strategies, such as descriptions of the actors involved. It looks at presupposed meanings, semantics and syntax on a microtextual level, tropes and other elements of symbolic meaning generation on a macro level. As for framing, the concept, widely used in Communication 
Science, can be defined as being the central organizing ideas in which complex messages are clad by focusing on one interpretation, suggesting what is and what is not essential about an issue (Gamson and Modigliani, 1989). Framing devices by which the frame can be identified are lexical choices, source selection, graphics, syntactical patterns in which certain actors are positioned in positive/negative semantic roles, or in active/passive roles, nominalization (by mystifying agency), and figurative language like metaphorical and metonymical conceptualization, which can function to stereotype or generalize the out-group.

The article integrates framing research from the discipline of Communication Studies with a Gramscian notion of media hegemony, as proposed by Carragee and Roefs (2004). In cultural studies, the theory of hegemony examines the role of a dominant ideology in affecting journalistic coverage of events. The analysis thus not only focuses on the type of frames that may emerge from the corpora, but also investigates whether there is room for a heteroglossic environment. Research therefore needs to uncover the ideological meanings largely consistent with the interests of powerful elites and investigate whether other ideological packages or frames from the margins emerge from the texts.

As for concrete methodology, a primarily qualitative discursive analysis gave rise to a limited content analysis with quantitative data so as to enable comparison of findings and retrieve frames, thematic hierarchies, and textual perspective. Frames and general tone could only be established on the basis of an accumulative count of textual framing devices which revealed evaluative positioning of the actors (in this case, Chinese government, China used metonymically, Chinese people, leading politicians, etc.), structures, relations or processes. These framing devices were given a positive or negative code depending on the connotation of the linguistic term selected by the journalist or voice quoted. ${ }^{4}$ The cumulative count of these codes resulted in a final assessment of the general textual perspective, based on five categories: very negative/positive; moderately negative/positive; neutral (either a balance between positive/negative codes or a mere factual description without evaluative positioning). A very negative/positive assessment of the depiction of the actors involved was derived at when the count of negative/positive codes rarely got counterweight by the opposite codes. A moderately negative/positive evaluation of the actor was determined on the basis of the ratio between the positive/negative codes per article. If the ratio exceeded $25 \%$, the article was coded as 'moderately' negative/positive, for example the ratio of 3 positive codes versus 8 negative evaluative instances is $37.5 \%$, giving rise to a moderately negative assessment of the article. Frames were determined when they occurred at least five times across the entire corpus per newspaper.

The selection of the newspapers was based on the overall national spread and on the papers' general attention to international news, thus eliminating the popular press which focuses mainly on local news reporting. This selection resulted for the Belgian papers in the following research units: (a) Dutch-language community: De Morgen (DM), De Standaard (DS), De Tijd (DT); (b) French-language community Le Soir $(L S)$, La Libre Belgique $(L L B)$. These newspapers are part of larger media 
concerns with commercial interests. Our selection takes one paper of each concern so that a considerable degree of editorial autonomy is guaranteed. From a historical point of view, $D S$ is pro-Flemish Catholic, $D M$ is progressive and generally perceived as having socialist orientations, $L L B$ Catholic and conservative (De Bens, 2001; Van Gorp, 2006). La Libre Belgique is known for its drive for unity within the Belgian state (Van Gorp, 2006: 152). Since its inception, Le Soir has seen itself as a paper independent of political parties or financial groups, but with clear political positions, at times quite liberal and anti-Flemish in the Belgian communitarian issue (De Bens, 2007: 424). De Tijd was conceived as a professional quality newspaper targeting the business world for its readership. For its editorial line, the newspaper used to profile itself as a provider of 'facts' with a distinct separation between pure information and opinion along the Anglo-Saxon model. Not unlike Le Soir, it dared to take position despite its independence of any stakeholder (establishment, readership, advertisers) (De Bens, 2007: 38).

The papers for the Netherlands were De Volkskrant (VK) and NRC Handelsblad $(\mathrm{NRCH})$. The Dutch NRC Handelsblad targets the highly educated and is known for its liberal stance (De Jong, 2013). De Volkskrant was formerly considered a leading center-left catholic newspaper and is today deemed to be a medium-sized centrist daily. Articles were retrieved through the Mediargus databank, currently named 'GoPress,' which is an archive of Dutch-language newspapers in Belgium, the web archives of Le Soir and La Libre Belgique, and the Lexis-Nexis databank for the Dutch newspapers. All articles were selected which featured China as their main focus and consisted of 300 words or more. This selection yielded a corpus of 1160 articles (DM: 139; DS: 198; LLB: 177; LS: 118; DT: 142; VK: 186; NRCH: 200), distributed over an average of 12 to 17 China-related articles per month per newspaper.

\section{Empirical analysis of the media narratives}

This section presents the main findings of the content analysis, followed by examples of the discursive analysis as an illustration of the framing process. Striking similarities emerge with the results of the study into German press coverage of China. Hence, cross-references will be made to the work of Richter and Gebauer (2011), whenever relevant.

\section{Content analysis}

We first offer a brief survey of prominent themes before moving to a discussion of text perspective or general tone. Next we take a look into the extent to which there are hegemonic articulations or whether there is room for a plurality of voices.

Thematic hierarchies. As for the distribution of themes, the following several news categories were established. Economic news includes financial news, trade, employment, mobility, and communication. Politics covers issues such as institutional 
reform, elections, organization of parliament and government, civil society, and state ideology (De Swert and Wouters, 2011: 345). The category of politics also comprises (political) international relations, issues of (political) international cooperation, war, and peace. Social news is constituted of all references to societal issues involving people's livelihood, including state/society relations, such as media working conditions, health and environmental issues, human rights issues, judicial themes, like crime and court cases, corruption. Other categories are education, science and technology (S\&T), culture and arts, sports, human interest (HI) stories (including natural disasters).

As demonstrated in Table 1, politics and economics are the two foremost news categories, closely followed by social issues, except for the newspaper De Tijd and the Dutch newspaper $N R C H$. This echoes the findings in the literature as outlined in part one. Two newspapers devote a considerable part of their China coverage to culture and arts, namely De Morgen and Le Soir, both known for their center-ofleft tendencies and a higher interest in societal issues, which is again evidenced in the number of articles on social issues, exceeding the ones on economic affairs. De Tijd appears to be least interested in arts and culture. Given its economic focus, it features the highest number of economic articles among all the newspapers with $69 \%$ of its overall China coverage. It shows the economic newsworthiness of the Chinese region for the Belgian business news consumer. The other newspapers devote between $6 \%$ and $10 \%$ of their China coverage to cultural issues. This corroborates the findings by Richter and Gebauer (2011) that cultural aspects had an 'unusual' weight with a $9.2 \%$ share of total reporting. Just as the authors found issues like education, science and technology to be completely disregarded, our results also show very low percentages, with most of the papers not reaching $1 \%$, except for LS and DM with $5 \%$ and $2.7 \%$, respectively.

The French-language La Libre Belgique spans the crown with the highest percentage of articles about social issues $(34.4 \%$ ), with a prime focus on human rights questions. It does not only record the highest percentage relative to the other topics

Table I. Theme distribution (in \% of total coverage per newspaper).

\begin{tabular}{lllllllll}
\hline & Economics & Politics & $\begin{array}{l}\text { Social } \\
\text { issues }\end{array}$ & Education & S\&T & $\begin{array}{l}\text { Culture, } \\
\text { Arts, Sports }\end{array}$ & HI & $\begin{array}{l}N \\
(=\#)\end{array}$ \\
\hline DM & 17.3 & 35.4 & 23.6 & 0.6 & 2.7 & 16.6 & 3.4 & 139 \\
DS & 36.4 & 29.1 & 22.3 & 1.4 & 0.5 & 8.2 & 1.9 & 198 \\
DT & 69 & 18.3 & 9.1 & 0 & 0 & 2.1 & 1.4 & 142 \\
LS & 25.4 & 32.2 & 18.6 & 0 & 5 & 13.5 & 5 & 118 \\
LLB & 29.3 & 24.2 & 34.4 & 0 & 0.5 & 9.6 & 1.6 & 177 \\
VK & 24.3 & 43.7 & 22.7 & 0 & 0.5 & 5.9 & 2.7 & 185 \\
NRCH & 33 & 38 & 14.5 & 0.5 & 4 & 6 & 4 & 200 \\
\hline
\end{tabular}


in its China coverage, but it also scores highest of all the newspapers in its attention to this news category. Another figure worth noting is the high percentage of the Dutch paper De Volkskrant with regard to political reporting (43.7\%), which turns out to be considerably higher than its attention to economic news $(24.3 \%)$. De Standaard, on the other hand, devotes a larger percentage to business articles $(36.4 \%)$ than to its narratives on politics $(29.1 \%)$ or social issues $(22.3 \%)$. Whether these results are statistically significant cannot be established for sure, since no statistical tests were conducted. Clearly, the low level of human interest stories or natural disaster testifies for the generally perceived elite-status of all the newspapers under investigation.

General tone about China as an actor. The evaluation of general tone or text perspective comprised five categories, ranging from very negative, moderately negative, neutral (balance of perspective or factual information), to moderately positive and very positive about the actor involved (China). The demarcation between the category 'very' and 'moderately' was, as explained above, determined by a ratio of positive/negative codes of $25 \%$. If the ratio exceeded $25 \%$, the article received a code of 'moderately' positive/negative (Table 2).

In general, $58.7 \%$ of the entire corpus registers negative assessments of China, with over one fourth of the articles scoring a very negative depiction of China. All newspapers publish over 20\% neutral articles (ranging from $22 \%$ to $28 \%$ ) and a low number of positive articles (16.1\%). This supports, once again, the findings of earlier research about negativity of China reporting. Among all newspapers, the financial newspaper De Tijd records the highest number of very negative accounts $(38.7 \%)$ as well as very positive articles $(20.4 \%)$. It means, that, considering its high number of economic articles, there are both positive and negative business-related

Table 2. Textual perspective per newspaper (in percentages).

\begin{tabular}{lllllllll}
\hline & $\begin{array}{l}\text { Very } \\
\text { negative }\end{array}$ & $\begin{array}{l}\text { Moderately } \\
\text { negative }\end{array}$ & $\begin{array}{l}\text { Total } \\
\text { negative }\end{array}$ & Neutral & $\begin{array}{l}\text { Moderately } \\
\text { positive }\end{array}$ & $\begin{array}{l}\text { Very } \\
\text { positive }\end{array}$ & $\begin{array}{l}\text { Total } \\
\text { positive }\end{array}$ & N (=\#) \\
\hline DM & 28.7 & 29.4 & 58.2 & 23 & 10 & 8.6 & 18.7 & 139 \\
DS & 29.7 & 27.2 & 57 & 26.7 & 10.6 & 5.5 & 16.1 & 198 \\
DT & 38.7 & 13.3 & 52.1 & 27.4 & 9.8 & 10.5 & 20.4 & 142 \\
LS & 26.2 & 31.3 & 57.6 & 26.2 & 11 & 5 & 16 & 118 \\
LLB & 36.7 & 26.5 & 63.2 & 22.5 & 9 & 5 & 14.1 & 177 \\
VK & 31.1 & 33.8 & 65 & 22 & 8 & 4.8 & 12.9 & 186 \\
NRCH & 26 & 30 & 56 & 28 & 14.5 & 1.5 & 16 & 200 \\
$(N)$ & $(N=360)$ & $(N=32 I)$ & $(N=68 I)$ & $(N=29)$ & $(N=122)$ & $(N=65)$ & $(N=187)$ & 1160 \\
$\%$ & $31 \%$ & $27.6 \%$ & $58.7 \%$ & $25.1 \%$ & $10.5 \%$ & $5.6 \%$ & $16.1 \%$ & \\
\hline
\end{tabular}


narratives. This finding is paralleled in the high number of neutral articles $(27.4 \%)$. The Tijd scores the second best after $N R C H$, which carries $28 \%$ neutral articles. Nevertheless, the number of overall negative articles in De Tijd is still more than double the number of positive articles. The other newspapers show a more lopsided picture with a ratio of nearly three negative articles to one positive narrative. In relative terms, the Dutch De Volkskrant features the lowest number of positively coded articles while topping the bill with the highest number of negative articles (65\%), closely followed by the French-language La Libre Belgique publishing $63.2 \%$ and $14.1 \%$ of negative and positive articles, respectively.

In absolute figures, the Dutch papers appear to print more articles than the Belgian counterparts, which may point at a higher perceived newsworthiness of China. It may also be related to the correspondents these papers post in China. This might at least be the case for De Volkskrant with its correspondent Fokke Obbema. For the Belgian newspapers, it is De Standaard that reports most on China, followed by La Libre Belgique, then De Morgen, and Le Soir. Important to note is the reporting source, which appears to have a major influence on the China perspective of the paper. Each paper employs some experts on China, who account for a large number of the articles and may be responsible for the general tone of the newspaper's coverage of China. For Volkskrant, Fokke Obbema delivers many contributions, whilst the lion share of articles for $N R C H$ is brought by Oscar Garschagen. For $D S$ it is Marije Vlaskamp and $L L B$ features many articles by Philippe Pacquet. In Le Soir, one comes across several articles by Anne Meijdam.Yet, one can often note a dual perspective with a difference in tone between articles originating from the foreign news desk and the correspondents, and the accounts stemming from the economic news desk.

Media hegemony or heteroglossia?. As concerns the production of hegemonic meanings by selectively giving a voice to only the powerful elites and constructing media frames consistent with their interests, findings demonstrate a plurality of voices, which testifies to a heteroglossic media environment. It can be argued that the Belgian and Dutch media do not only cater to the interests of powerful elites. However, whenever the Chinese official voice appears, it is usually privileged elite actors, such as government spokespeople, ministers or the president and premier. Local cadres are less quoted, but this may be a consequence of the difficult access of foreign journalists to local sources. As Richter and Gebauer (2011: 6) argue, 'journalists often rely on a small circle of easily-accessible dissidents or activists for an alternative view to the official line.' Furthermore, the Chinese political leadership is said to rarely explain domestic policy processes in unambiguous language. Therefore, 'foreign journalists generally have to rely on the state media and press releases as secondary sources' (2011:6). The same holds true for the lack of diversification of popular voices. Usually the same type of dissidents makes it to the media, like the controversial artist Ai Weiwei, who has gained the status of a regular media source, thus receiving 'standing,' i.e. being treated as an agent with a voice. As suggested by Richter and Gebauer (2011) about the German press 
coverage of China, more differentiation between active participants in Chinese current events and their contrary views and diverging interests (central government versus local cadres) is also in order for the Dutch and Belgian press.

Secondly, and not unlike the results of the German study (Richter and Gebauer, 2011), journalists appear to side with the victims of the political system that is perceived to be authoritarian. Yet, a variety of perspectives emerges in all newspapers, also giving a voice to government officials, thus presenting various lines of argumentation, albeit not equally balanced and tilting in favor of the dissidents.

\section{Discourse analysis: Evaluative positioning and framing}

In tandem with the many positive frames about China as the leading economic actor in the world, and an attractive growth market, one can find negative framings of China as an (unreliable) economic rival, threatening domestic labor conditions and, more on a global scale, threatening Western economies because of their overdependence on the Chinese (unreliable) creditor. Besides the topic selection, the us/ them constellation within a villain/victim framework or the antinomous anchoring of the familiar us versus the exotic and strange them, appears to be shaped by the national (ideological) self-positioning in relation to the Chinese political and economic model, and grounded in assumptions that China's rise will entail the old continent's decline. The articles are replete with stereotypical images, based on deeply entrenched symbols and stock phrases, such as 'export machine,' 'koophonger' [purchasing hunger], 'overname machine' [takeover machine], 'loempiacultuur' [pancake roll culture]. This, again, echoes the findings of Richter and Gebauer (2011).

Many articles with the dominant frames of China as an authoritarian regime, a control freak ruthlessly engaging in censorship and depriving its subjects of basic human rights are marked by a Eurocentric perspective, cherishing values such as the rule of law, democracy, respect for individual rights and the like. Due to the overall focus on human rights issues, giving much media mileage to minority issues and dissidents, issues of modernity and social transformation, including education and migration problems sparking civil protests, do not receive due attention. Positive developments, such as Chinese innovation in science and technology are sporadically mentioned (like in $D M, L L B$, and $L S$ ), but are not salient enough to translate into frames.

Other negative frames are those of the Chinese authorities fighting immense environmental problems, and the increasing social gap between certain Chinese citizens desperately trying to survive in dire living and work conditions and others leading a life of luxury, mostly laced with corruption and fraudulent business practices. Just as demonstrated by Richter and Gebauer (2011), our results indicate a general lack of a more comprehensive reporting.

Yet, it must also be underlined that at times one can find nuanced exploration of processes, events, relations by statements that are preceded or followed by contrasting propositions. For example, one article nuances the negative framing of 
Chinese censorship, by adding that the PRC foreign film policy is easing up. ${ }^{5}$ However, the positive statements are refuted more often than the negative ones.

Additionally, some journalists appear to shy away from direct incrimination of China by emphasizing place rather than action with a neutralizing effect, as in 'Drie Tibetanen sterven door zelfverbranding in China' [Three Tibetans die by selfimmolation in China]. ${ }^{6}$ In a syntactical construction like 'De Tibetanen voelen zich al decennialang door Chinezen onderdrukt' [The Tibetans have been feeling oppressed by the Chinese for decades], the addition of the qualification 'feel' to the predicate indicates that Chinese oppression is not presupposed but located in the experiential or mental world of Tibetans.

Since the reporting rests on an event-driven agenda, China is depicted in a rather monolithic way, and just as in the German study, no differentiation is made between all active participants in Chinese current events and their contrary views and diverging interests (Richter and Gebauer, 2011: 8). Another similarity concerns the unreflective use of collective derogatory terms such as 'gangsterocracy,' 'cleptocracy' or generalizations such as 'China' or 'the Chinese.' Categorizations and generalizations often create denunciatory images of Chinese society and adopt a cliché-ridden or stereotypical format. The article 'Clevits' illustrates the functioning of accumulated stereotypes, such as 'loempiafeest' [pancake roll festival], 'ministel-plesident,' 'nieuwe gele invasie' [new yellow invasion]. ${ }^{7}$ Not only does the Chinese leadership get deprecatory comments, also the ordinary Chinese are not described in flattering terms. They are said to be focused on external looks. ${ }^{8}$

While all actors get a voice, state elites still dominate coverage. Yet, they very often remain amorphous as a 'regime' or 'government.' Metonymical use of 'Peking/Pékin' endows the actors hidden behind this term with collective power. It not only simplifies a complex amalgam of actors but obscures particular actions, structures, processes, and relations. Additional generalization is realized by using generic nouns preceded by definite articles, presupposing propositional existence, such as 'de gevestigde belangen [the vested interests],' 'de stugge bureaucratie ['the stiff bureaucracy'], 'de bankensector' [the banksector], 'de corruptie [the corruption],' 'de kloof tussen arm en rijk [the gap between poor and rich].' All these characterizations are posited as if they were inherent to the state system and present fluid conditions as fixed realities. The reductionist functioning of nominalized constructions, such as 'hervormingen' [reforms], 'le fonctionnement de la Justice Chinoise' [the functioning of the Chinese justice], eliminates contextualization which can be achieved by mentioning actors, relations of cause and effect, and the like.

A powerful contributor to the framing process is lexical cohesion, where synonyms shape a particular semantic field. By accumulation and repetition of certain nouns/noun phrases and predicates an atmosphere is created, sometimes positive when it concerns the economic progress or the Chinese entrepreneurial spirit, at other times quite inimical, relating to issues such as corruption, fraud, hacking practices, or unhealthy life conditions. In $N R C$ Handelsblad, for example, the term 'cancer village' is repeated 14 times in one article, (published on 21 March 
2013) and headlined 'Ook de katten willen weg uit 'kankerdorp' Jinling [Also the cats want to leave the 'cancer village' Jinling]. From a macro-perspective, the negative tone is already set in the headline. A combination of word groups such as 'la répression [the repression],' 'il est interdit [it is forbidden],' 'clandestinement [stealthily],' positioned in proximity, evokes an authoritarian frame.

In addition, negatively connotated actional verbs, such as 'bloquer (sur internet)' [block on internet] or colored adjectives like 'sanglante (repression)' [bloody (repression)] enhance the disparaging image of China. Indeed, China is very often positioned in a negative semantic role, as the actor of verbs with negative connotation, like 'provoke,' 'orchestrate,' 'crush,' as in 'les autorités cherchent à écraser le mouvement de contestation' [the authorities look for crushing the contestation movement]. ${ }^{9}$ Even in the economic realm, China is at times depicted in a negative active role of aggressor, as in 's'attaquer au marché européen' [to attack the European market]. Explicit predicates in the non-modalized indicative mood and simple present tense draw a crystal clear, negative image of China as an unfair and greedy economic superpower, e.g. 'in this shadowy sector the Chinese are unmatched.' ${ }^{10}$ The next sentence illustrates the same discursive practice, strengthened by an adverbial qualification: 'baby abandonments are not rare in China where the one-child policy applies often in a brutal way.' 11

Chinese culture, on the other hand, is often framed in positive and valuable terms by syntactical enumeration of positive labels, enhanced by modifiers, such as 'de rêve' [dreamlike] and adjectival qualifiers, as in 'haute (precision)' [high (precision)], 'grande (dextérité)' [high (dexterity)]. Superlatives like 'les plus grandes' [the largest] strengthen the image. Noteworthy, though, positive descriptions appear only when describing collective culture of the past or individual cultural products/workers of the present. Collective contemporary culture is not framed positively, for example the Chinese film policy. A negatively oriented questioning technique, as in 'On ne vous a pas poussé au compromis?' [You have not been pushed to a compromise?] steers the reader toward preferred answers. ${ }^{12}$

Rhetorical devices are not only stylistic embellishments of the texts, but contribute to the framing process. Metaphors, privileging negative conceptualizations over alternatives, abound. For example, the election of President Xi Jinping is described as a 'theater performance,' or economic imports of solar panels are depicted in terms of 'flooding' and more generally, China is described as 'the Chinese giant' ['le géant chinois']. Equally, tongue-in-cheek understatements often appear, such as 'niet meteen een hoogmis van de democratie' [not immediately a High Mass of democracy'], predicated of the Chinese National People's Congress. $^{13}$

Irony and sarcasm shine through modifying expressions such as 'surprise encore' [one more surprise], 'peu étonnant' [barely surprising], or implicature-triggering adverbs like 'finalement' [finally]. An ironical rhetorical question already embeds the answer, like 'Op zoek naar een echte uitdaging? Overweeg eens cartoonist te worden in China, in de voetsporen van Kuang Biao' [Looking for a real challenge? Consider becoming a cartoonist in China, in the footsteps of Kuang Biao]. ${ }^{14}$ 
The same effect is reached by subtitles with rhetorical questions, like 'Symbole de liberté? [Symbol of liberty?]., 15

Historical comparisons reverberant of Cold War, anti-communist rhetoric often emerge through references to continuities with Maoist times and comparisons with the Soviet Union. Outdated clichés such as 'Chine Maoïste,' 'pays totalitaire [totalitarian country],' 'tyrannie [tyranny],' 'rode prinsen' [red princes] abound.

Texts are replete with scare quotes, as a typographical sign of modality where the author takes distance from the propositional content. Another rhetorical device is antinomy or contrast between the various actors, be it the Chinese government put in the active steering wheel versus the Chinese citizens, who are often portrayed as the passive victims, ${ }^{16}$ although oftentimes the dissidents get more voice than the Chinese leadership. Opposition is also created between China as an eccentric, willful world player and the familiar Western 'us.' Positive attributes of the Western ingroup are contrasted with negative properties predicated of the Chinese out-group.

\section{Conclusion}

In general, it emerges from the data that the five newspapers use similar discursive practices. Comparable frames emerge through accumulation of the abovementioned linguistic features. The only salient differences appear to lie in topic selection, given the particular focus of the newspapers, for example, the business oriented De Tijd, which devotes more attention to economic issues. Obviously, some stories of particular relevance to the domestic audience in the Netherlands, Wallonia or Flanders are highlighted over others. This confirms domestication theories, arguing that mainstream news organizations select those stories with news values for the domestic audience in terms of cultural and geographical proximity. This can be illustrated by the shifting perspectives in the stories of Le Soir relating to the panda transfers to the Walloon amusement park Pari Daiza, which triggered tension between the Flemish zoo in Antwerp and Pari Daiza. Whilst other articles in Le Soir adopt a critical tone against the Chinese government, in this dossier, there were three neutral articles and one relatively positive article. Another example of domestication, seen in all newspapers, is the attention to the negative consequences of unreliable Chinese investment practices for the local economies.

This analysis validates much of what is already known about foreign news coverage of China. In spite of China's economic impact on the world and its importance in international affairs and the increased attention to China which has moved China into an elite group of nations in terms of news coverage (Sparks, 2010; Willnat and Luo, 2011), it is only covered marginally in Belgian international news reports. The limited number of articles per month can attest to that.

When it comes to prominence of topics, former studies already argued that foreign TV news does not only offer insufficient coverage of China, but it should also pay more attention to China's cultural and social issues (Cohen, 2011: 252; Willnat and Luo, 2011: 270). Similarly, our analysis of the Belgian and Dutch press 
narratives about China shows that positive/negative aspects of the transforming Chinese society get 'drowned in the river of other stories' (De Swert and Wouters, 2011: 343) on economic and political issues relevant to Western audiences. Our findings thus support Willnat and Luo's conclusion that 'China is consistently portrayed by the [sic] Western media with frames that focus on human rights, political containment, and economic trade' (Willnat and Luo, 2011: 259). Yet, it must be acknowledged that, just as TV coverage witnessed an increase in verbal and visual attention to daily life in China and to the consequences of the rapid social and economic transition of China, enabled by the presence of a foreign correspondent for the public Belgian TV channel (De Swert and Wouters, 2011: 343), the written Belgian press also features human interest stories and covers social issues, thus giving a voice to a multitude of actors, including ordinary people, albeit only sporadically.

Another point worth our attention is that much of the evaluative positioning of actors rests on the origin of the article. Correspondents like Fokke Obbema for de Volkskrant have an overwhelming influence in the overall framing process, just because of the large number of articles authored by the same hand. Other journalists who feature regularly are Anne Meijdam for De Volkskrant, Oscar Garschagen for NRC Handelsblad, Marije Vlaskamp for De Standaard, Philippe Pacquet for La Libre Belgique. Moreover, distinction needs to be made between articles originating from different editorial newsdesks. In De Volkskrant, for example, articles produced by the foreign newsdesk appear to be more negative than the ones written by the economic editorial team, which points at a dual track policy.

A third parallel between the current and previous studies is the overall negative assessment of China. Most coverage focused on stories about economy, and conflict, often framing China in a negative way, just as Belgian TV coverage of China appears to have more negative references than positive ones (De Swert and Wouters, 2011: 342). The news coverage appears to be quite one-dimensional focusing on human rights abuses and the growth of the Chinese economy. The depiction of a powerful economic rival to the European business community and by extension a potential danger to the world economy due to a perceived overdependence on the Chinese economic magnet, nurtures and orients this collective thought toward a more irrational sentiment of a threat to the us-category by the outsiders. This produces intolerance and fear instead of true understanding.

Yet, despite the overall negative assessment of China, both positive as well as negative frames appear from the data. Findings of the current study thus support results from Wilke and Achatzi's (2011) longitudinal study about the framing of China in the German press in that the assessment of China does not appear to take a linear development as positive or negative frames alternate depending on emerging events or crises. The importance of context is also pointed out by De Swert and Wouters (2011), acknowledging the fact that, since their study is concerned with news as a category, findings are highly dependent upon actual events in China. In other words, the presence of peaks in the number of news items suggests at least partly event-driven journalism (2011: 339). ${ }^{17}$ Proof of this was also found in our 
corpus analysis. At the moment of difficult EU-China trade negotiations concerning the anti-dumping measures relating to the cheap solar panel imports, negative articles emerge with colorful metaphors from the trenches/war domain, but as soon as the trade talks find a peaceful solution, more positive articles are printed concerning promising fruitful collaboration and China/EU as trade partners. This finding corresponds with the focus on context in the study by Huang and Leung (2005), who argue that the negative coverage of China in the Western press mostly results from China's own policies and actions rather than the deliberate agenda-setting or bias of foreign journalists (2005), since the Vietnamese official handling of the SARS crisis received a more positive treatment in the Western press than the Chinese one.

And even beyond the contextual factor of emerging events/crises, it must be underlined that one can find nuanced exploration of processes, events, relations by statements that are often preceded or followed by contrasting propositions, although the positive statements are still refuted more often than the negative ones.

Apart from confirming certain framing trends discovered in previous studies, this analysis primarily illustrated linguistic properties of the framing process. It was designed to serve as a qualitative support to previous studies on Western media representation of China, which conducted quantitative content analyses, providing quantitative data about general tone, discussing longitudinal trends in theme selection, balance of voices, and article sourcing. This particular study focused on the textual aspect of the framing process and demonstrated how image-building and positioning of the Self and the Other is engaged in by accumulation of a diversity of discursive strategies on both the micro- and macro-level. Deconstructing the framing process is a way to resist stereotypical imaginaries of fixed identities in terms of us/them polarities, imaginaries of fear and conflict and manipulation of simplistic ideas.

\section{Declaration of Conflicting Interests}

The author declared no potential conflicts of interest with respect to the research, authorship, and/or publication of this article.

\section{Funding}

The author(s) disclosed receipt of the following financial support for the research, authorship, and/or publication of this article: The author(s) received financial support from the European Commission under the LLP Jean Monnet Programme (Education, Audiovisual \& Culture Agency) for the research, authorship, and/or publication of this article.

\section{Notes}

1. The present essay is part of a longitudinal project mapping the Belgian press coverage of China from 2008 onwards. Exploration of Belgian media narratives about China has been conducted since 2008 in collaboration with students of the master program of Journalism, Faculty of Arts, KU Leuven Campus Brussels. Credit and gratitude goes to the students for help with data collection and primary analysis. This article only maps the results of the 2013 investigation. Yet, the trend noticed over the preceding years is mirrored in the 2013 corpus. 
2. Message by Lulu Wang retrieved from http://www.Geledraak.nl/html/showarticle.asp? id $=1585$ (accessed on 17 April 2008).

3. Similar findings were found in a comparative study by Lams of the China coverage in the Dutch-language elite and more popular newspapers in 2008.

4. Inevitably, coder subjectivity cannot be excluded at this level, although final conclusions about ideological patterns can only be derived at when they emerge on various structural levels of analysis without any counter-indication. The coding was realized by a group of 48 students, whom I trained to retrieve ideology from texts. Yet, the final results' overwhelming clarity offsets any coder subjectivity.

5. In article 'Censuur van Django frustreert Chinezen' [Censorship of Django frustrates Chinese], De Standaard, 16 April 2013.

6. In article 'Drie Tibetanen sterven door zelfverbranding in China' [Three Tibetans die by self-immolation in China], De Standaard, 25 April 2013.

7. In this article 'Clevits,' the author makes fun of the phonetic lack of distinction between 1/r sounds in the Chinese language (De Tijd, 12 September 2013).

8. In article «Aziatisch middenklasse verkiest echte Lego boven namaakblokjes » [Asian middle class prefers real Lego to fake blocks], De Tijd, 6 September 2013.

9. In article 'Un village Chinois exige la démocratie' [a Chinese village demands democracy], Le Soir, 10 March 2014 . Other examples are « China die [...] opvreet, China die [...] de hele regio in crisis kan storten [China that... devours; China that.... can plunge the entire region in crisis] in article 'China zoekt naar een alternatief voor harde repressie in Tibet' [China looks for an alternative for hard repression in Tibet']? NRC Handelsblad, 1 July 2013; 'zij worden gedwongen een knieval te maken voor de Chinese autoreiten' [they are forced to kowtow for the Chinese authorities] in article 'China weigert wegens conflict Hollywood miljoenen te betalen' [China refuses to pay millions because of conflict Hollywood], NRC Handelsblad, 31 July 2013; 'Xi Jinping kondigt aan om dissidente geluiden de kop in te drukken' [Xi Jinping announces to quell dissident sounds], in article 'Chinese media op Marx-cursus' [Chinese media on Marxcourse], NRC Handelsblad, 28 August 2013.

10. Original text: 'Want tegenwoordig zijn hackers niet meer zo rood; ze kiezen voor 'zwart'; de ondergrondse economie van cybercriminaliteit. In die schimmige sector zijn de Chinezen ongeëvenaard. Tenminste, dat zeggen de Verenigde Staten' (De Standaard, 10 June 2013 'Hacken in dienst van Peking is zo saai' [hacking in the service of Peking is so boring]). This quote is weakened by the modifying addition that this proposition stems from the United States. Yet, by the sheer selection of the quote, the image is set, no matter where it originates.

11. In article 'Chine: un bébé jeté dans les toilettes sauvé » [a baby thrown in the lavatory, saved]. Original text: «Les abandons de bébés ne sont pas rares en Chine, où s'applique de façon souvent brutale la politique de l'enfant unique,' La Libre Belgique, 28 May 2013.

12. In article 'Wong Kar Wai renaît dans les arts martiaux' [Wong Kar Wai is reborn in the martial arts], Le Soir, 30 April 2013.

13. In article 'Alle hens aan dek voor 'Chinese droom' [all hands on deck for 'Chinese dream'], De Standaard, 6 March 2013.

14. In article 'Chinese censuur heeft handen vol met cartoons van Broeder Kuang' [Chinese censorhip has its hands full with cartoons of Brother Kuang], De Morgen, 12 April 2013. 
15. In article 'Hong Kong fait ses adieux à son gros canard jaune' [HK says goodbye to its large yellow duck], La Libre Belgique, 9 June 2013.

16. Examples of passive roles reserved for Chinese ordinary people are the following: 'schadevergoeding wordt toegekend [compensation is granted], 'werd ontvoerd en verkracht' [were abducted and raped], 'werden gearresteerd en veroordeeld' [were arrested and condemned], etc. in article 'Moeder dwingt Chinese overhead tot knieval' [Mother forces Chinese authorities into genuflexion], NRC Handelsblad, 17 July 2013.

17. Despite the event-driven character of the China coverage, results also showed that the impact of a correspondent increased the China coverage, also during periods in which no special events took place (De Swert and Wouters, 2011: 339).

\section{References}

Carragee, Kevin M and Roefs W (2004) The neglect of power in recent framing research. Journal of Communication 54: 214-233.

Clifford J (1988) The Predicament of Culture: Twentieth-Century Ethnography, Literature, and Art. Cambridge, MA: Harvard University Press.

Cohen AA (2011) Editorial: Covering China: Inside and out. Chinese Journal of Communication 4: 251-254.

De Bens E (2001) De pers in België: het verhaal van de Belgische dagbladpers gisteren, vandaag en morgen. Leuven: Lannoo.

De Bens E and Raeymaeckers K (2007) De pers in België: het verhaal van de Belgische dagbladpers gisteren, vandaag en morgen. Leuven: Lannoo.

Decoster K (2008) Door welke lens kijken wij naar China? Mo*Magazine, 22 July, pp. 3-35.

De Jong S (2013) Liberalisme in NRC Handelsblad: klassiek, met soms een radicale bui. Available at: http://www.nrc.nl/ombudsman/2013/04/06/liberalisme-in-nrc-handelsbladklassiek-met-soms-een-radicale-bui (accessed on 10 June 2013).

De Swert K and Wouters R (2011) The coverage of China in Belgian television news: A case study on the impact of foreign correspondents on news content. Chinese Journal of Communication 4: 331-347.

Gamson WA and Modigliani A (1989) Media discourse and public opinion on nuclear power: A constructionist approach. American Journal of Sociology 95: 1-37.

Höijer B (2011) 'Social representations theory: A new theory for media research. Nordicom Review 32: 3-16.

Huang Y and Leung CCM (2005) Western-led press coverage of Mainland China and Vietnam during the SARS crisis: Reassessing the concept of media representation of the 'other'. Asian Journal of Communication 15: 302-318.

Jonckheere J (2008) Hoe ‘spontaan' waren de Tibet-rellen. China Vandaag, June, pp. 28-31.

Kobland CE, Du L and Kwon J (1992) Influence of ideology in news reporting case study of New York Times' coverage of student demonstrations in China and South Korea. Asian Journal of Communication 2: 64-77.

Lams L (2010) Linguistic tools of empowerment and alienation in the Chinese official press: Accounts about the April 2001 Sino-American diplomatic standoff. Pragmatics 20: 315-342.

Lams L (2013) Representations of the three T's (Tibet, Turkestan and Taiwan) in the Belgian press during the run-up to the Beijing Olympics: A comparative analysis of Dutch- and French-language narratives. In: Mertens S (ed.) Perspectieven op Internationale Journalistiek. Gent: Academia Press, pp. 45-64. 
Lee CC (2002) Established pluralism: US elite media discourse about China policy. Journalism Studies 3: 343-357.

Moscovici S (2000) Social Representations. Explorations in Social Psychology. Cambridge, UK: Polity Press.

Olausson U (2010) Towards a European identity? The news media and the case of climate change. European Journal of Communication 25: 138-152.

Ono KA and Jiao JY (2008) China in the US imaginary: Tibet, the Olympics, and the 2008 earthquake. Communication and Critical/Cultural Studies 5: 406-410.

Peng Z (2004) Representation of China: An across time analysis of coverage in the New York Times and Los Angeles Times. Asian Journal of Communication 14: 53-67.

Richter C and Gebauer S (2011) The Portrayal of China in German Media. Berlin: HeinrichBöll-Stiftung, pp. 1-10. Available at: http://www.boell.de (accessed 6 February 2012).

Riggins SH (1997) The Language and Politics of Exclusion. Thousand Oaks, CA: SAGE.

Said E (2003) Orientalism. London: Penguin (reprint; originally published in 1978, Routledge and Kegan).

Sparks C (2010) Coverage of China in the UK national press. Chinese Journal of Communication 3: 347-365.

Stone GC and Xiao Z (2007) Anointing a new enemy: The rise of anti-China coverage after the USSR's demise. Gazette 69: 91-108.

Van Gorp B (2006) Framing Asiel: Indringers en Slachtoffers in de Pers. Leuven: Acco.

Wilke J and Achatzi J (2011) From Tian'anmen Square to the global world stage: Framing China in the German press, 1986-2006. Chinese Journal of Communication 4: 348-364.

Willnat L and Luo Y (2011) Watching the dragon: Global television news about China. Chinese Journal of Communication 4: 255-273.

Wu M (2006) Framing AIDS in China: A comparative analysis of US and Chinese wire news coverage of HIV/AIDS in China. Asian Journal of Communication 16: 251-272.

Zhang L (2010) The rise of China: Media perception and implications for international politics. Journal of Contemporary China 19: 233-254.

Zhao Y (2013) Communication, crisis and global power shifts. Keynote speech at the China Communication Forum and the First Central Asian Communication Forum, 20-22 September 2013, School of Journalism and Communication, Xinjiang University, Urumqi, PR China. 